\title{
Analyzing Ocular and Systemic Findings of Patients with Down Syndrome
}

\author{
- Ayşin Tuba Kaplan, (․) Ayse Yesim Oral, 을 Nilufer Zorlutuna Kaymak, \\ (1) Mehmet Can Özen, (1) Şaban Şimşek
}

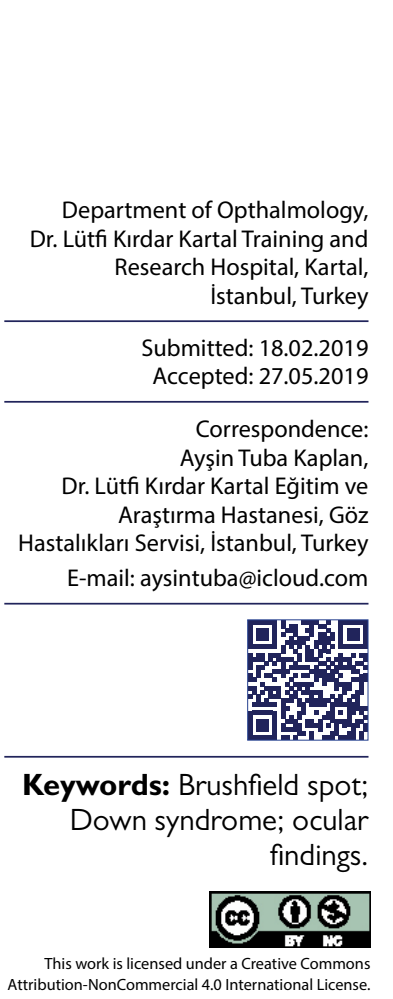

\begin{abstract}
Objective: The aim of this study was to analyze the ocular and clinical findings of patients with Down syndrome.

Methods: A total of 72 patients, aged between 4 months and 22 years (mean: $5.5 \pm 5.1$ years), were included in the study. All of the patients had been genetically analyzed and diagnosed with Down syndrome. The results of eye examinations and the accompanying systemic findings of the patients were obtained from computer records and the families. A visual acuity assessment, biomicroscopy, fundus examination, cycloplegic refraction, and in required cases, a fluorescein dye disappearance test, were performed.
\end{abstract}

Results: Of the 72 patients, 48 (67\%) were male and 24 (33\%) were female. Chromosome analysis revealed regular trisomy in 69 patients (96\%), a genetic mosaic in 2 patients (3\%), and a translocation pattern in I patient (I.4\%). The results of the eye examination of patients revealed refractive errors (85\%), upward slanting of the palpebral fissures (68\%), epicanthus (63\%), strabismus (33\%), blepharitis $(22 \%)$, retinal pathologies (19\%), cataract $(19 \%)$, nasolacrimal duct obstruction (I7\%), Brushfield spots (I7\%), eyelid laxity (I I\%), nystagmus (4\%), and keratoconus (3\%). The systemic findings identified were congenital heart disease $(36 \%)$, hypothyroidism (3l\%), growth retardation (7\%), hearing loss $(6 \%)$, undescended testis $(4 \%)$, asthma (4\%), Hirschsprung's disease (I.4\%), and autism (I.4\%). No refractive error was observed in II patients (15\%), and no systemic disease was seen in 13 patients (19\%). Astigmatism was the most frequent finding $(68 \%)$, followed by hyperopia $(47 \%)$ and myopia $(19 \%)$. The most common congenital heart disease was a septum defect (33\%).

Conclusion: Ocular problems and systemic diseases are more common in patients with Down syndrome. Early diagnosis and treatment will make it easier for patients to adapt to all aspects of life.

\section{INTRODUCTION}

Trisomy 21, also known as Down syndrome, was first described by Edouard Onesimus Seguin in 1846, but was first introduced to the literature with written data in 1866 by John Langdon. ${ }^{[1]}$ The incidence is 1:750-1000 in neonates. , and it is the most common chromosomal disease in humans. ${ }^{[2]}$ Its main features include typical facial and head appearance (cranio-facial dysmorphism), varying degrees of mental retardation, hypothyroidism, congenital heart defects, gastrointestinal (GIS) problems, ocular anomalies, hearing impairment, and immunodeficiency.

Chromosome analysis of Down syndrome cases revealed complete trisomy 21 resulting from meiotic "non-disjunction" with a rate of $95 \%, 4 \%$ translocation and $1 \%$ mosaicism. ${ }^{[3]}$ While the somatic cell chromosome structure of the parents of the patients with complete trisomy 21 was found to be normal and 47 chromosomes were detected due to "non-disjunction" during gametogenesis, in translocation Down syndrome, in addition to two copies Chromosome 21 that are free, there is a third copy of chromosome 21 that is translocated to chromosome 14 , 21 and rarely 22 . In the mosaic type, normal and trisomic cell lines coexist as a result of post-zygotic division error, but the clinical picture is usually similar. ${ }^{[4]}$

Ocular findings of patients with Down syndrome are diverse and these findings are not diagnostic. They can be also seen rarely in normal individuals or in patients with other mental and physical defects. Pathologies such as epicanthus, upward slanting palpebral fissures, eyelid laxity, iris and retinal anomalies can be seen in these cases, as well as refractive errors, cataract, strabismus, lacrimal drainage problems, keratoconus, nystagmus and amblyopia that may cause serious problems. The nature of the anom- 
alies in Down syndrome cases indicates that the globe is affected in the late stage of embryological development. While some of the findings are present at birth, some of them appear as the child grows up. ${ }^{[5]}$

Although congenital heart defects are the most common systemic diseases, hypothyroidism, GIS anomalies, hearing problems, neuromuscular disorders, musculoskeletal disorders and immunological disorders are also common.

Although Down Syndrome cases can be easily recognized by their phenotypic features, related systemic diseases and ocular findings, there are various clinical variations among patients. Therefore, we aimed to investigate the ocular and associated systemic findings of patients with Down syndrome admitted to our clinic.

\section{MATERIALS AND METHODS}

A total of 72 patients with Down syndrome who were examined in the outpatient clinic between January 2016 and March 2018 were included in the study. Chromosomal analysis of all cases was obtained by short-term cell cultures of lymphocytes in genetic diagnosis centers and patients had definitive diagnosis as Down syndrome. In addition to eye examinations, the systemic findings of the patients were obtained from computer records and, if necessary, from their families, and by requesting a pediatric and cardiology consultation. Visual acuity examination, cycloplegic refraction, biomicroscopy and fundus examination were performed, and when necessary, fluorescein dye disappearance test was performed in all patients.

Visual acuity was measured with Snellen chart according to age and compliance of the cases. Refractive errors were calculated by taking cycloplegic spherical equivalent into account. The difference between refractive error of 1.0 diopters (D) and above between the two eyes was considered as anisometropia, and values out of $-1.0 \mathrm{D}$ and +2.0 $D$ range were considered as ametropia. Cylindrical values of one diopter and above were accepted as astigmatism.

The features of palpebral fissure, presence of eyelid pathologies such as epicanthus and eyelid laxity were investigated. $2 \mathrm{~mm}$ or more upward and outward incilination of lateral canthal angle from the medial canthal angle; was considered as 'upward slanting palpebral fissure'. The term eyelid laxity is used for eyelids that spontaneously show eversion backward when the child cries or when the lid is opened for examination.

Eyelids, conjunctiva, cornea, iris and lens examinations were performed by biomicroscopy in compatible patients. Incompatible patients were examined macroscopically with the aid of light source or indirect ophthalmoscope. The presence of strabismus was examined in primary position with Hirschberg and/or cover-uncover test, and the angle of deviation, if any, was determined by Krimsky or prism cover test. Eye movements were evaluated and presence of limitation and excessive functions and nystagmus were recorded.
All cases received I\% cycloplegine drop (I\% cyclopentolate hydrochloride) for refraction and fundus examination. A history of epiphora and/or fluorescein dye disappearance test revealed nasolacrimal duct obstruction.

\section{RESULTS}

A total of 72 Down syndrome patients (48 male and $24 \mathrm{fe}-$ male), aged between 4 months and 22 years (mean $5.5 \pm 5$. I years) were included in the study. Chromosome analysis revealed trisomy 21 in 69 patients (96\%), mosaic in 2 patients (3\%) and translocation pattern in I patient (I.4\%) (Table I).

The most common ocular problem was refractive error (85\%). Forty-nine patients (68\%) had astigmatism, 34 patients (47\%) had hyperopia, 4 patients (19\%) had myopia, while 13 patients (18\%) had anisometropia. Eleven (I5\%) cases had no refractive errors.

When the eyelid problems were evaluated; upward eyelid slanting was found in 49 cases in 45 (63\%), blepharitis in $16(22 \%)$, eyelid laxity in $8(11 \%)$ and bilateral upper eyelid ectropion in I case. Nasolacrimal duct obstruction was present in 12 cases (17\%).

Strabismus was detected in 24 (33\%) patients, 20 (83\%) of them had esotropia and 4 (I7\%) had exotropia. No vertical deviation was detected in any of our patients. Nystagmus was detected in 3 cases (4\%), all of whom were operated for bilateral white cataracts. Nystagmus was horizontal in 2 cases and rotary in I case.

Cataract was detected in 14 cases (19\%). Four cases (29\%) had sutural cataract, 4 cases $(29 \%)$ had blue dot cataract, 3 cases $(21 \%)$ had bilateral white mature cataract and 3 cases $(21 \%)$ had posterior polar cataract.

Iris anomalies was present in 17 cases (24\%). Of these, 12 (7I\%) had Brushfield spots, 4 (23\%) had stromal hypoplasia, and I (6\%) had iris coloboma. Only 2 patients (3\%) had keratoconus as a corneal pathology.

Retinal and optic nerve changes were detected in 14 cases (19\%). Increased retinal pigmentation was present in 7 cases (50\%), peripapillary atrophy in 2 cases (14\%), blurring of the optic nerve margins and increased vascular tortuosity in 2 cases (14\%), car wheel image made by the vessels originating from the optic nerve in I case (7\%), degenerative myopia findings in I case $(7 \%)$ and choroid coloboma in I case (7\%) (Table 2).

Table I. Characteristics of Down syndrome cases

\begin{tabular}{lcc}
\hline Gender & Total & $\%$ \\
\hline Female & 48 & 67 \\
Male & 24 & 33 \\
Karyotypr & & \\
Regular Type & 69 & 96 \\
Mozaic & 2 & 3 \\
Translocation & 1 & 1.4 \\
\hline
\end{tabular}


Table 2. Ocular findings of Down syndrome cases

\begin{tabular}{lcc}
\hline Ocular findings & Total & $\%$ \\
\hline Refractive error & & \\
$\quad$ Astigmatism & 49 & 68 \\
Hyperopia & 34 & 47 \\
Myopia & 14 & 19 \\
Eyelid disorder & & \\
$\quad$ Upward slanting palpebral fissure & 49 & 68 \\
Epicanthus & 45 & 63 \\
Blepharitis & 16 & 22 \\
NLD occlusion & 12 & 17 \\
$\quad$ Eyelid laxity & 8 & 11 \\
$\quad$ Ectropion & 1 & 1.4 \\
Strabismus & 24 & 33 \\
Cataract & 14 & 19 \\
Iris pathology & 17 & 24 \\
$\quad$ Brushfield spot & 12 & 71 \\
Iris hypoplasia & 4 & 23 \\
Iris coloboma & 1 & 6 \\
Optic nerve-retina pathology & 14 & 19 \\
Nystagmus & 3 & 4 \\
Keratoconus & 2 & 3 \\
\hline & &
\end{tabular}

Table 3. Systemic findings of Down syndrome cases

\begin{tabular}{lcc}
\hline Systemic findings & Total & $\%$ \\
\hline Congenital heart diseases & 26 & 36 \\
$\quad$ VSD & 19 & 73 \\
$\quad$ ASD & 5 & 19 \\
$\quad$ PDA & $\mathrm{I}$ & 4 \\
$\quad$ Tetralogy of Fallot & $\mathrm{I}$ & 4 \\
Hypothyroidism & 22 & $3 \mathrm{I}$ \\
Developmental retardation & 5 & 7 \\
Hearing loss & 4 & 6 \\
Undescended testis & 3 & 4 \\
Asthma & 3 & 4 \\
Inguinal-umbilical hernia & 3 & 4 \\
Torticollis & 2 & 3 \\
Hirschsprung's disease & $\mathrm{I}$ & 1.4 \\
Duodenal atresia & $\mathrm{I}$ & $\mathrm{I}$ \\
Laryngomalacia & $\mathrm{I}$ & $\mathrm{I}$ \\
Autism & $\mathrm{I}$ & $\mathrm{I}$ \\
\hline
\end{tabular}

The most common systemic disease was congenital heart defects $(36 \%)$. Of these, 19 (73\%) had ventricular septal defect, 5 (19\%) had atrial septal defect, I (4\%) had patent ductus arteriosus and I (4\%) had tetralogy of Fallot. In addition, when accompanying systemic diseases are examined; congenital hypothyroidism was seen in 22 cases ( $31 \%)$, developmental delay in 5 cases (7\%), GIS anomalies in 5 cases (7\%), hearing loss in 4 cases $(6 \%)$, undescended testicle in 3 cases (4\%), asthma in 3 cases (4\%), torticol- lis in 2 cases (3\%), laryngomalacia in I case (1.4\%) and autism in I case (1.4\%). Of cases with GIS anomaly, three cases $(4 \%)$ had inguinal-umbilical hernia, I case $(1.4 \%)$ had Hirschsprung's disease, and I case (I.4\%) had duodonal atresia. In 14 cases (19\%), no accompanying systemic diseases were detected (Table 3).

\section{DISCUSSION}

In addition to the intelligence levels and general appearance of Down syndrome patients, systemic and ocular findings are of great importance in the follow-up of the patients.

Eyelid pathologies were the most frequently encountered ocular findings in patients with Down syndrome. Epichantal fold has been reported in the literature at variable rates between $9-100 \%$, while the slanting of the lid has been reported as high as $43-94 \% .^{[6,7]}$ In our study, the incidence of epichantus was $63 \%$ and of the slanting lids, it was $68 \%$. It has been suggested that different rates in the literature may be related to age, racial factors and measurement techniques. ${ }^{[8]}$ Blepharitis was detected at a rate of $22 \%$ in our study, while the incidence of blepharitis was found between $10-30 \%$ in the meta-analysis of 11 articles by Creavin et al. ${ }^{[9]}$ There are studies that link the high incidence of blepharitis in Down syndrome to disorders of the immune system, as well as these patients being more susceptible to infection due to abnormal structure of the eyelid. ${ }^{[10,11]}$ The loose eyelids and the lids rotating out easily can be considered to cause the conjunctiva to be exposed to external factors and providing the ground for infection. While the rate of nasolacrimal duct obstruction in Down syndrome patients varied between 5-30\% in various studies, this rate was found to be $17 \%$ in our study. ${ }^{[7,8,12]}$ Catalano et al. reported that nasolacrimal duct obstruction was not associated with Down syndrome and decreased with age as in the normal population. ${ }^{[10]}$ Slanting eyelids was detected in II\% of our cases. In the literature, there are no reports on the rate of loose eyelids, while there are case reports of eversion of both upper eyelids. ${ }^{[8]}$

Compared with the normal population, refractive errors are more common in Down's syndrome cases. ${ }^{[13-19]}$ Since different criteria are used for the definition of refractive error, ametropia has been reported in variable rates in the studies. While the frequency of hyperopia, which has been calculated using spherical equivalent varies between $20-40 \%$ in the studies, hyperopia was found to be higher than myopia. ${ }^{[20-25]}$ In the studies related to accommodation, it was observed that accommodation ranges were significantly lower in Down syndrome cases compared with similar age groups. ${ }^{[26-28]}$ Jaeger reported $46 \%$ myopia, $28 \%$ hyperopia and $26 \%$ astigmatism in his study with Down syndrome patients, while Shapiro and France reported $27 \%$ myopia and $25 \%$ astigmatism. ${ }^{[6,29]}$ In a study by Watt et al., hyperopia was reported as $56 \%$, myopia as $25 \%$, and astigmatism as $74 \% .{ }^{[30]}$ In our study, the most common error was astigmatism (68\%), followed by hyperopia (47\%) and myopia (19\%). In contrast to the control group, it was observed that re- 
fractive errors gradually increased in preschool period in Down syndrome cases. They attributed this to an insufficiency of infant emmetropization process in cases with Down syndrome. Although it is not fully understood why emetropization does not proceed properly, it has been suggested that accommodative insufficiency, the lack of close activity in contrast to the high rate of outdoor activity, and the changes in the visual cortex were cited as the causes. ${ }^{[30]}$ Also, delayed correction of refractive errors due to difficulties in visual examination of these cases and other systemic disorders may slow down the emetropization process.

The presence of nystagmus in Down syndrome cases has been reported in various studies as 4-30\%. ${ }^{[12-14,3 \mid, 32]}$ Shapiro and France reported that the nystagmus detected in $9 \%$ of their cases was horizontal and not related to ocular anomalies. ${ }^{[29]}$ These authors suggest that nystagmus in Down syndrome may be due to an undetectable central nervous system defect or an unidentified retinal pathology. In our study, congenital bilateral cataract was present in 3 cases (4\%) with nystagmus. Esotropia was also present in these patients who underwent cataract surgery. Nystagmus was horizontal in two patients and rotatory in one patient. Nystagmus was detected in $23 \%$ of patients with esotropia in the study of Heller et al., ${ }^{[33]}$ while Jaeger reported nystagmus rate as $8 \%{ }^{[6]}$

Strabismus rate is higher in Down syndrome cases than in general population. ${ }^{[5,34-37]}$ In their study, Haugen and Hovdig reported that accommodative strabismus was more frequent (46\%) in Down syndrome, especially due to high hyperopia. ${ }^{[6]}$ Yurdakul et al. also reported the frequency of esotropia as $18 \%$ in Down syndrome cases. [38] While the incidence of strabismus was $33 \%$ in our patients, $83 \%$ were esotropia and $17 \%$ were exotropia. No vertical deviation was detected in any of our patients.

Various authors have reported the incidence of cataracts in patients with Down syndrome ranging from $5 \%$ to $37 \%$. [30] In a Danish study, the incidence of cataracts at birth was found as $1.4 \%$ in Down syndrome cases and as $0.06 \%$ in the normal population. ${ }^{[39]}$ The incidence of cataract was $19 \%$ in our cases. Four patients $(5.5 \%)$ had sutural cataract, four patients (5.5\%) had blue dot cataract, three patients $(4 \%)$ had white mature cataract, and three patients (4\%) had posterior polar cataract. In studies, while the most common in Down syndrome cases were blue dot or punctate opacities, it is mentioned that the incidence of opacities increases with age. ${ }^{[40]}$

Although Brushfield spots are not pathognomonic signs of Down syndrome, its presence is considered as a complementary parameter. Its incidence was reported to be between $10-90 \%$ in the literature, while in our study, it was $17 \% .{ }^{[5,13,41]}$ These spots are yellow-white, ring-shaped structures seen in the iris stroma, but are less likely to occur in dark iris. It was seen that all of our patients who had Brushfield spots had light iris color. This can be explained by the fact that the darker iris is more common in regards to race and the rare occurrence of spots with dark iris. Bişkin et al. found Brushfield spots in $22 \%$ of Down syn- drome cases, Yurdakul et al. found in 27\%, and Da Cunha et al. found in $52 \% .^{[5,12,38]}$

Iris hypoplasia is seen in $8-17 \%$ of normal population, while it was reported as $34-48 \%$ in Down syndrome cases. [7,42,43] In addition, there are several publications about both Brushfield spots and iris hypoplasia are not seen at all in Down syndrome patients. ${ }^{[22,44-47]}$ In these studies it is mentioned that it may not be seen especially in races with dark iris. While the rate of iris hypoplasia was $5.5 \%$ in our cases, Yurdakul et al. reported it as $4 \%$ and Bişkin et al. reported as $30 \% .^{[5,38]}$

The most commonly reported changes in the posterior segment of the eyes in patients with Down syndrome are the car wheel image originating fom increased vessels, hyperemia of the optic nerve, degenerative fundus appearance, peripapillary choroidal atrophy, retinal pigmentation changes, retinoblastoma and retinal detachment. ${ }^{[5,39,45,47]}$ In our study, retinal anomalies were found in $19 \%$. The most common fundus findings were increased retinal pigmentation (10\%), while peripapillary atrophy $(2.8 \%)$, blurring of the optic nerve margins and increased vascular tortuosity (2.8\%), car wheel image (1.4\%), degenerative fundus changes (I.4\%) and choroid coloboma (1.4\%) were other findings.

The most common systemic disease in Down syndrome cases is reported as congenital heart defects in the literature. Several studies have reported that the most common congenital heart defects are atrioventricular septal defect, ventricular septal defect, isolated secundum type atrial septal defect, isolated persistent patent ductus arteriosus and isolated tetralogy of Fallot. ${ }^{[48-50]}$ In our study, congenital heart defects were seen in $36 \%$, and $73 \%$ of them were ventricular septal defect, 19\% were atrial septal defect, $4 \%$ were patent ductus arteriosus and $4 \%$ were tetralogy of Fallot. Congenital heart defects were reported in $40 \%$ in a study in Egypt, $44 \%$ in a US study, $46 \%$ in a prospective study in Europe, and $18 \%$ in another retrospective study in India. ${ }^{[44,51,52]}$ As seen from the results, approximately half of the patients with Down syndrome are born with congenital heart defects. Therefore, routine echocardiography in the neonatal period is recommended in these patients.

While the incidence of hypothyroidism in the normal population is I in 4000 live births, this rate is approximately 28 times higher in newborns with Down syndrome and occurs in a rate of $I$ in $141 . .^{[53]}$ In a large series study in the USA, the incidence of thyroid dysfunction in newborns with Down syndrome was reported as $0.1 \%$, and in a study in Kuwait, as $52 \% .{ }^{[33,54]}$ In our cases, congenital hypothyroidism was found in $31 \%$. The fact that hypothyroidism between races was seen at different rates is explained by geographical differences, nutrition and genetic predisposition. ${ }^{[4]}$ Periodic evaluation of thyroid functions in patients with Down syndrome is important both for the persistence of normal development and to prevent further worsening of existing mental retardation.

It is reported that the incidence of GIS pathologies in Down syndrome cases is 20 times higher than the nor- 
mal population. ${ }^{[5]}$ GIS anomalies include duodenal atresia, Hirschsprung's disease, omphalocele, duodenal bands, ileal and jejunal atresia and diaphragmatic hernias. In their study, Abbag et al. found that GIS anomalies as $22.4 \%$, and duodenal atresia was the most common anomaly, while Kallen et al. reported that the frequency of annular pancreas and duodenal atresia increased 300 -fold..$^{[56,57]}$ In our study, the incidence of GIS anomalies was $7 \%$ and inguinalumbilical hernia was the most common (4\%).

Head circumference, weight and height are low in newborns with Down syndrome and growth retardation is common compared to the normal population. ${ }^{[55]}$ It has been reported that patients with congenital heart disease have more frequent growth retardation than those without. [58] There was developmental retardation in our 5 patients (7\%), all of which were operated due to cardiac problems.

Evaluation of hearing loss in patients with Down syndrome is crucial because it affects the intellectual development. 38-78\% of patients with Down syndrome have hearing loss. ${ }^{[46,48]}$ It has been reported that ear infections are common due to weak immune system, flattened face, variety in head bones and narrow sinuses, and hearing loss develops in $5 \%$ of the cases within I year after infection. ${ }^{[55]}$ In our study, there were 4 patients (6\%) with hearing loss.

Apart from the aforementioned systemic diseases, various hypotonia, speech disorders, microcephaly, holoprosencephaly, convulsions, spinal cord compression, Alzheimer's disease, dementia, autism, undescended testes, asthma and torticollis are also seen in varying rates in patients with Down syndrome. ${ }^{[5]]}$ Also in our study, there were cases with undescended testes $(4 \%)$, asthma (4\%) and autism (1.4\%).

Down syndrome is easily recognizable by its characteristic features and associated systemic malformations. Early clinical diagnosis is very important to combat the problems related to the syndrome. Early intervention to the problems that may adversely affect somatic and intellectual development such as hypothyroidism, congenital heart defects, ophthalmologic and otological problems will provide more positive responses in the treatment of patients. The support and education is essential and necessary for this families.

Ethics Committee Approval

Approved by the local ethics committee.

Informed Consent

Retrospective study.

Peer-review

Internally peer-reviewed.

Authorship Contributions

Concept: A.T.K., N.Z.K.; Design: A.T.K., A.Y.O.; Supervision: A.T.K., N.Z.K. M.C.Ö.; Fundings: A.T.K., M.C.Ö.; Materials: N.Z.K., M.C.Ö.; Data: A.T.K., N.Z.K., A.Y.O.; Analysis: A.T.K., A.Y.O., Ş.S.; Literature search: A.T.K., A.Y.O., Ş.S.; Writing: A.T.K., A.Y.O.; Critical revision: A.Y.O., Ş.Ş.

Conflict of Interest

None declared.

\section{REFERENCES}

1. Berg JM, Korossy M. Down syndrome before Down: a retrospect. Am J Med Genet 2001;102:205-11. [CrossRef]

2. Antonarakis SE, Lyle R, Dermitzakis ET. Chromosome 21 and Down syndrome: from genomics to pathophysiology. Nat Rev Genet 2004;5:725-38. [CrossRef]

3. Pangalos C, Avramopoulos D, Blouin JL, Raoul O, deBlois MC, Prieur $\mathrm{M}$, et al. Understanding the mechanism(s) of mosaic trisomy 21 by using DNA polymorphism analysis. Am J Hum Genet 1994;54:473-81.

4. Gardiner K, Davisson M. The sequence of human chromosome 21 and implications for research into Down syndrome. Genome Biol 2000;1:review0002. [CrossRef]

5. Bişkin F, Duranoğlu Y, Altın M. Down sendromlu olgularda göz bulguları. Türkiye Klinikleri J Ophthalmol 2005;14:17-24.

6. Jaeger EA. Ocular findings in Down's syndrome. Trans Am Ophthalmol Soc 1980;78:808-45.

7. Solomons G, Zellwegeger H, Jahnke PG. Four common eye signs in mongolism. Am J Dis Child 1965;110:46-50. [CrossRef]

8. Miller R, Martin F, Allen H. A case of congenital ectropion in Down's syndrome. Aust N Z J Ophthalmol 1988;16:119-25. [CrossRef]

9. Creavin AL, Brown RD. Ophthalmic abnormalities in children with Down syndrome. J Pediatr Ophthalmol Strabismus. 2009;46:76-82.

10. Catalano RA. Down syndrome. Surv Ophthalmol. 1990;34:385-98.

11. Millis EA. Ocular findings in children. In: Lane D, Stratford B, editors. Current approaches to Down's syndrome. London: Holt Rinehart and Winston; 1985. p. 103-18.

12. da Cunha RP, Moreira JB. Ocular findings in Down's syndrome. Am J Ophthalmol. 1996;122:236-44. [CrossRef]

13. Berk AT, Saatci AO, Erçal MD, Tunç M, Ergin M. Ocular findings in 55 patients with Down's syndrome. Ophthalmic Genet 1996;17:15-9.

14. Caputo AR, Wagner RS, Reynolds DR, Guo SQ, Goel AK. Down syndrome. Clinical review of ocular features. Clin Pediatr (Phila) 1989;28:355-8. [CrossRef]

15. H Al-Hussain, A A Al-Rajhi, S Al-Qahtani, D Meyer. Congenital upper eyelid eversion complicated by corneal perforation. $\mathrm{Br} \mathrm{J}$ Ophthalmol 2005;89:771. [CrossRef]

16. Haugen $\mathrm{OH}, \mathrm{Høv}$ ding G. Strabismus and binocular function in children with Down syndrome. A population-based, longitudinal study. Acta Ophthalmol Scand 2001;79:133-9. [CrossRef]

17. Skeller E, Øster J. Eye symptoms in mongolism. Acta Ophthalmol (Copenh) 1951;29:149-61. [CrossRef]

18. Gardiner PA. Visual defects in cases of Down's syndrome and in other mentally handicapped children. Br J Ophthalmol 1967;51:469-74.

19. Woodhouse JM, Pakeman VH, Cregg M, Saunders KJ, Parker M, Fraser WI et al. Refractive errors in young children with Down syndrome. Optom Vis Sci 1997;74:844-51. [CrossRef]

20. Stirn Kranjc B. Ocular abnormalities and systemic disease in Down syndrome. Strabismus 2012;20:74-7. [CrossRef]

21. Mohd-Ali B, Mohammed Z, Norlaila M, Mohd-Fadzil N, Rohani CC, Mohidin N. Visual and binocular status of Down syndrome children in Malaysia. Clin Exp Optom 2006;89:150-4. [CrossRef]

22. Kim JH, Hwang JM, Kim HJ, Yu YS. Characteristic ocular finding in Asian children with Down syndrome. Eye (Lond) 2002;16:710-4.

23. Stephen E, Dickson J, Kindley AD, Scott CC, Charleton PM. Surveillance of vision and ocular disorders in children with Down syndrome. Dev Med Child Neurol 2007;49:513-5. [CrossRef]

24. Ljubic A, Trajkovski V, Stankovic B. Strabismus, refractive errors and nystagmus in children and young adults with Down syndrome. Ophthalmic Genet 2011;32:204-11. [CrossRef]

25. Bromham JM, Woodhouse JM, Cregg M, Webb E, Fraser WI. Heart defects and ocular anomalies in children with Down's syndrome. Br J 
Ophthalmol 2002;86:1367-8. [CrossRef]

26. Woodhouse JM, Meades JS, Leat SJ, Saunders KJ. Reduced accommodation in children with Down syndrome. Invest Ophthalmol Vis Sci 1993;34:2382-7.

27. Nandakumar K, Leat SJ. Bifocals in children with Down syndrome (BiDS)-Visual acuity, accommodation and early literacy skills. Acta Ophthalmol (Copenh) 2010;88:e196-204. [CrossRef]

28. Anderson HA, Manny RE, Glasser A, Stuebing KK. Static and dynamic measurements of accommodation in individuals with down syndrome. Invest Ophthalmol Vis Sci 2011;52:310-7. [CrossRef]

29. Shapiro MB, France TD. The ocular features of Down's syndrome. Am J Ophthalmol 1985;99:659-63. [CrossRef]

30. Watt T, Robertson K, Jacobs RJ. Refractive error, binocular vision and accommodation of children with Down syndrome. Clin Exp Optom 2015;98:3-11. [CrossRef]

31. Hiles DA, Hoyme SH, McFarlane F. Down's syndrome and strabismus. Am Orthopt J 1974;24:63-8. [CrossRef]

32. Wagner RS, Caputo AR, Reynolds RD. Nystagmus in Down's syndrome. Ophthalmology 1990;97:1439-44. [CrossRef]

33. Averbuch-Heller L, Dell'Osso LF, Jacobs JB, Remler BF. Latent and congenital nystagmus in Down syndrome. J Neuroophthalmol 1999;19:166-72. [CrossRef]

34. Renie WA. Goldberg's genetic and metebolic eye disease. LittleBrown; 1986: p. 212-7.

35. Cregg M, Woodhouse JM, Stewart RE, Pakeman VH, Bromham NR, Gunter HL et al. Development of refractive error and strabismus in children with Down syndrome. Invest Ophthalmol Vis Sci 2003;44:1023-30. [CrossRef]

36. Geeraets WJ. Ocular Syndromes, 3rd ed. Philadelphia: Lea \& Febiger; 1976. p. 146.

37. Roy FH. Ocular differential diagnosis. Philadelphia: Lea \& Febiger; 1989: p. 54, 89, 90, 315, 438.

38. Yurdakul NS, Ugurlu S, Maden A. Strabismus in Down syndrome. J Pediatr Ophthalmol Strabismus 2006;43:27-30.

39. Haargaard B, Fledelius HC. Down's syndrome and early cataract. $\mathrm{Br}$ J Ophthalmol. 2006;90:1024-7. [CrossRef]

40. Joseph Igersheimer. The Relationship of Lenticular Changes to Mongolism. Trans Am Ophthalmol Soc 1951;49:595-624.

41. Atkinson J, Anker S, Bobier W, Braddick O, Durden K, Nardini M et al. Normal emmetropization in infants with spectacle correction for hyperopia. Invest Ophthalmol Vis Sci 2000;41:3726-31.

42. Duke-Elder S. System of opthalmology, congenital deformities. Henry-Kimpton; Vol 3, Part 2, 1972. p. 1135-7.
43. Schlagel TF. Differential diagnosis masquerade syndromes. In: Duane TD, editor. Clinical ophthalmology. Philedelphia: Harper\&Row; Vol 4, Chap. 59, 1984. p. 1.

44. Afifi HH, Abdel Azeem AA, El-Bassyouni HT, Gheith ME, Rizk A, Bateman JB. Distinct ocular expression in infants and children with Down syndrome in Cairo, Egypt: myopia and heart disease. JAMA Ophthalmol 2013;131:1057-66. [CrossRef]

45. Fimiani F, Iovine A, Carelli R, Pansini M, Sebastio G, Magli A. Incidence of ocular pathologies in Italian children with Down syndrome. Eur J Ophthalmol 2007;17:817-22. [CrossRef]

46. Liza-Sharmini AT, Azlan ZN, Zilfalil BA. Ocular findings in Malaysian children with Down syndrome. Singapore Med J 2006;47:14-9.

47. Wong V, Ho D. Ocular abnormalities in Down syndrome: an analysis of 140 Chinese children. Pediatr Neurol 1997;16:311-4. [CrossRef]

48. Van Allen MI, Fung J, Jurenka SB. Health care concerns and guidelines for adults with Down syndrome. J Med Genet 1999;89:100-10.

49. Figueroa R, Magana BP. Heart malformations in children with Down syndrome. Rev Esp Cardiol 2003;56:894-9. [CrossRef]

50. Vida VL, Barnoya J, Larrazabal LA, Gaitan G, de Maria Garcia F, Castañeda AR. Congenital cardiac disease in children with Down's syndrome in Guatemala. Cardiol Young 2005;15:286-90. [CrossRef]

51. Al-Jarallah AS. Down's syndrome and the pattern of congenital heart disease in a community with high parental consanguinity. Med Sci Monit 2009;15:CR409-12.

52. Stoll C, Alembik Y, Dott B, Roth MP. Study of Down syndrome in 238,942 consecutive births. Ann Genet 1998;41:44-51.

53. Fort P, Lifshitz F, Bellisario R, Davis J, Lanes R, Pugliese M. et al. Abnormalities of thyroid function in infants with Down syndrome.J Pediatr 1984;104:545-9. [CrossRef]

54. Ali FE, Bayoumy HA, Mohammad AS, Al-Busairi WA, Al-Othman AN. Thyroid function in Kuwaiti subjects with Down's syndrome. Med Princ Pract 2002;11:206-9. [CrossRef]

55. Tolmie JL. Down's syndrome and other autosomal trisomies. In: Rimoin D, O'Connor JM, Pyeritz RE, Emergy AEH, editors. Principles and practices of medical genetics. 3rd ed. Scotland: WB Saunders, Livingstone; 1997. p. 925-71.

56. Abbag FI. Congenital heart diseases and other major anomalies in patients with Down syndrome. Saudi Med J 2006;27:219-22.

57. Källén B, Mastroiacovo P, Robert E. Major congenital malformations in Down Syndrome. Am J Med Genet 1996;65:160-6. [CrossRef]

58. Reller MD, Morris CD. Is Down syndrome a risk factor for poor outcome after repair of congenital heart defects? J Pediatr 1998;132:73841. [CrossRef]

\section{Down Sendromlu Hastaların Göz ve Eşlik Eden Sistemik Bulgularının İncelenmesi}

Amaç: Kliniğimize başvuran Down sendromlu hastaların göz ve eşlik eden diğer klinik bulgularını incelemeyi amaçladık.

Gereç ve Yöntem: Çalışmamıza, yaşları 4 ay ile 22 yaş (ort. 5.5 5 .I) arasında değişen 72 olgu dahil edildi. Tüm olguların genetik analizi yapılmış olup Down sendromu tanısı almışlardı. Göz muayeneleri dışında olguların eşlik eden sistemik bulguları da bilgisayar kayıtlarından ve gerekli hallerde ailelerinden bilgi alınarak elde edildi. Olgulara görme keskinliği ölçümü, biyomikroskopi, fundus muayenesi, sikloplejik refraksiyon muayenesi ve gereken olgularda floresein boya kaybolma testi yapıldı.

Bulgular: Çalışmaya dahil edilen 72 olgunun 48'i (\%67) erkek, 24'ü (\%33) kız idi. Kromozom analizlerinde, 69 olguda (\%96) regüler trizomi, 2 olguda (\%3) mozaik, I olguda (\%।.4) ise translokasyon paterni tespit edildi. Olguların göz muayenelerinde; refraksiyon kusuru (\%85), yukarı kapak eğimi (\%68), epikantus (\%63), şaşılık (\%33), blefarit (\%22), retina anomalileri (\%।9), katarakt (\%।9), nazolakrimal kanal tıkanıklığı (\%।7), Brushfield lekesi (\%।7), kapak gevşekliği (\%II), nistagmus (\%4) ve keratokonus (\%3) tespit edilirken; sistemik hastalık olarak konjenital kalp hastalığı (\%36), hipotroidizm (\%3।), gelişme geriliği (\%7), işitme azlı̆̆ı (\%6), inmemiş testis (\%4), astım (\%4), Hirschsprung hastalı̆ı (\%।.4) ve otizm (\%।.4) saptandı. Olguların I I'inde (\%I5) hiçbir göz patolojisine rastlanılmadığı gibi, I3 olguda (\%।9) sistemik hastalığa rastlanmadı. En sık astigmatizma (\%68) tespit edilirken bunu sırasıyla hipermetropi (\%47) ve miyopi (\%/9) izledi. Konjenital kalp hastalıklarından ise en sık septum defektleri (\%33) tespit edildi.

Sonuç: Down sendromlu olgularda göz problemleri ve sistemik hastalıklar sık görülmektedir. Erken dönemde yapılacak doğru tanı ve tedavi ile hastaların eğitim hayatına ve sosyal hayata uyumu daha kolay olacaktır.

Anahtar Sözcükler: Brushfield lekesi; Down sendromu; göz bulguları. 